\title{
X-ray Examination of the Complex Adenosine, Guanosine and Cytidine with $\mathrm{UO}_{2}{ }^{2+}$ Ions
}

\author{
Aibassov Yerkin Zhakenovich ${ }^{1 *}$, Yemelyanova Valentina ${ }^{1}$, Shakieva Tatyana ${ }^{1}$, Nakisbekov Narymzhan ${ }^{2}$, \\ Tussupbaev Nessipbay ${ }^{1}$, Abenov Bakhyt ${ }^{1}$, Bulenbayev Maxat ${ }^{1}$, Dossumova Binara ${ }^{1}$ and Blagikh Evgeniy ${ }^{1}$ \\ 1. Research Institute of New Chemical Technologies and Materials, Kazakh National University Al-Farabi, Almaty 005012, \\ Kazakhstan
}

2. Institute of Fundamental and Applied Medicine, Kazakh National Medical University, Almaty 005012, Kazakhstan

\begin{abstract}
Interaction of dioxouraniun (VI) $\mathrm{UO}_{2}{ }^{2+}$ ion with Adenosine-5'-triphosphate, Guanosine-5'-triphosphate and Cytidine-5'-triphosphate were obtained a complexs of Adenosine, Guanosine and Cytidine with uranium $\mathrm{UO}_{2}{ }^{2+}$ ions and $\mathrm{X}$-ray method to explore these complexes.
\end{abstract}

Key words: DNA, uranyl ion, X-ray, Adenosine, Guanosine, Cytidine complexs.

\section{Introduction}

Metal complex formation of nucleotides is well documented, as well as its biological importance. Metal-nucleotide complex may act as cofactor, substrate or modifier in promoting enzymatic catalysis of displacement reactions of phosphorus and maintaining structural integrity and specificity of nucleic acids. Nucleotides bing metal through three potential binding sitcs: phosphate groups, sugar hydroxo groups and ring nitrogen of base [1-13].

The purpose of this work is to obtain a complex of adenosine with uranium $\mathrm{UO}_{2}{ }^{2+}$ and thorium $\mathrm{Th}^{4+}$ ions and $\mathrm{X}$-ray method to explore these complexes.

\section{Experimental Sections}

Dioxouranium (VI) $\left(\mathrm{UO}_{2}{ }^{2+}\right)$ and thorium $\left(\mathrm{Th}^{4+}\right)$ cations was used as nitrate salts. ATP (5'-adenosine 5'-triphosphate), ADP (5'-adenosine 5'-diphosphate), AMP (5'-adenosine 5'-monophosphate), CTP (5'-cytidine triphosphate), CDP (5'-cytidine diphosphate), CMP (5'-cytidine monophosphate), GDP (5'-guanosine diphospate), was used as disodium salt.

\footnotetext{
*Corresponding author: Aibassov Yerkin Zhakenovich, professor, research field: organic chemistry of U, Th, As, Sb, Bi. E-mail: erkin53@mail.ru.
}

\section{Results and Discussion}

In Ref. [1] has been studied interaction of dioxouranium (VI) (uranyl) ion with ATP was studied by ligand/proton and metal/hydroxide displacement technique, at very low ionic strength and at $\mathrm{I}=0.15$ $\mathrm{mol} \cdot \mathrm{L}^{-1}$, in aqueous $\mathrm{Me}_{4} \mathrm{NCl}$ and $\mathrm{NaCl}$ solutions, at $\mathrm{t}=$ $25{ }^{\circ} \mathrm{C}$.

The interaction of adenosine with uranyl ions is described by the Eq. (1):

$$
\begin{aligned}
& \mathrm{pUO}_{2}{ }^{2+}+\mathrm{q}\left(\mathrm{ATP}^{4-}\right)+\mathrm{rH}^{+} \rightarrow \\
& \quad\left(\mathrm{UO}_{2}\right)_{\mathrm{p}}(\mathrm{ATP})_{\mathrm{q}} \mathrm{H}_{\mathrm{r}}^{(2 \mathrm{p}-4 \mathrm{q}+\mathrm{r})}
\end{aligned}
$$

Analysis of the complex of adenosine with uranium $\mathrm{UO}_{2}{ }^{2+}$ and thorium $\mathrm{Th}^{4+}$ ions was performed by X-ray microanalysis. Instrument: electron probe microanalyzer. Brand: Superprobe 733, Japan Electron Optics Laboratories, Japan.

The analysis of the elemental composition of the resulting of the microsphere magnetic catalyst with salts of Thorium and of Uranium was performed using energy-dispersive spectrometer Energy Oxford Instruments, England, established by electron probe microanalyzer Superprobe 733 at an accelerating voltage of $25 \mathrm{kV}$ and a probe current of $25 \mathrm{nA}$. 


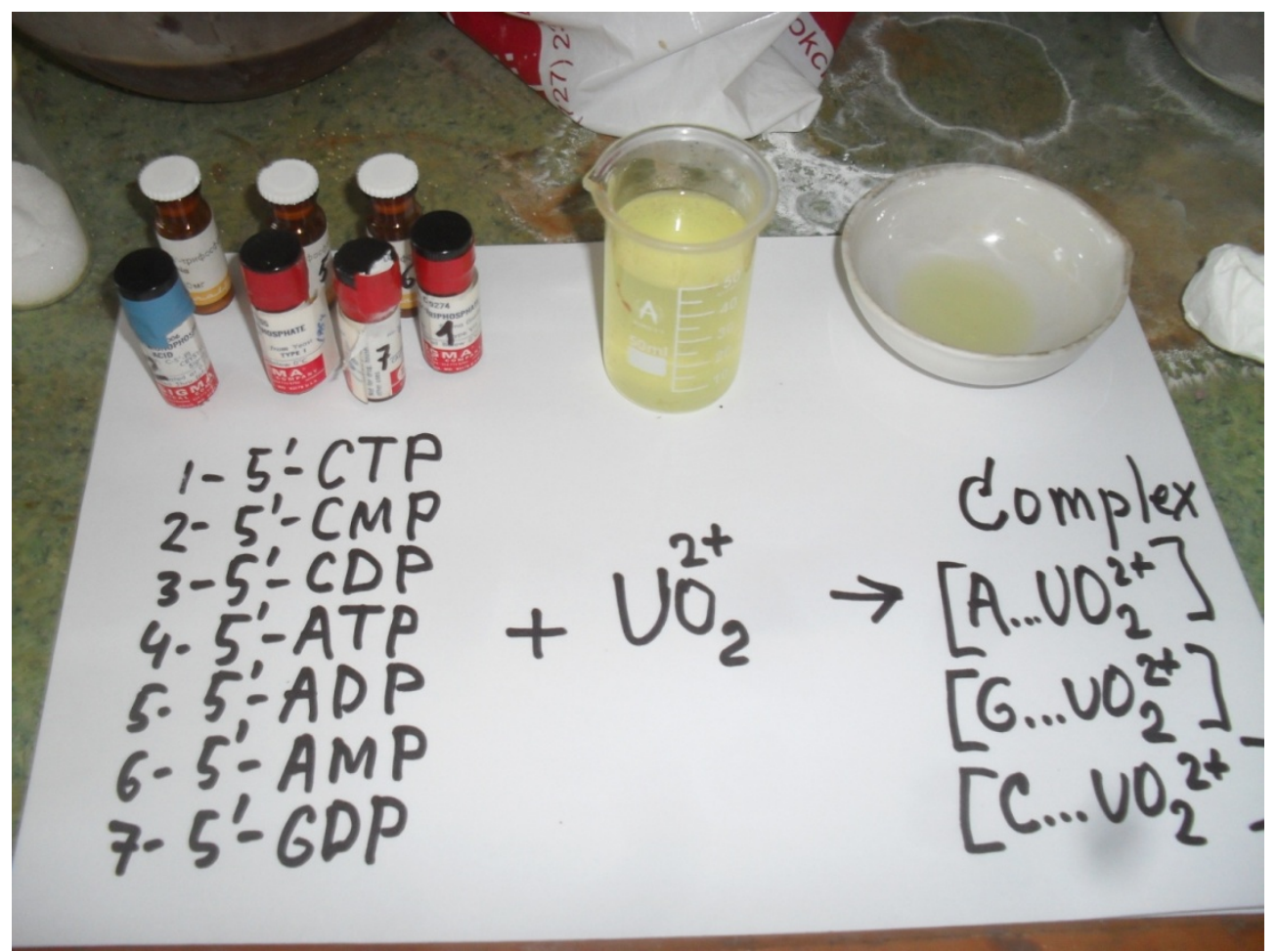

Fig. 1 Obtained a complex of $\mathrm{A}, \mathrm{G}, \mathrm{C}$ with $\mathrm{UO}_{2}{ }^{2+}$.

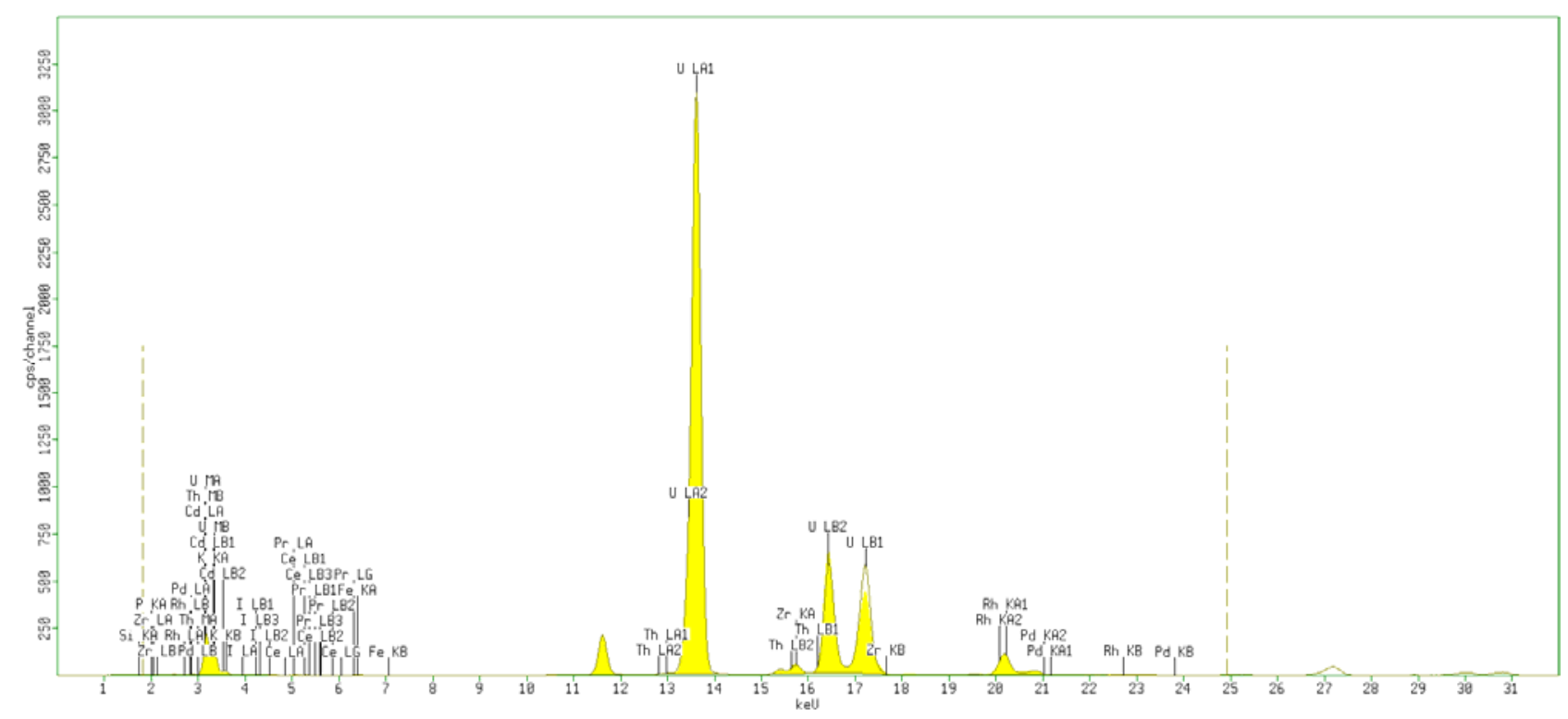

Fig. 2 X-ray spectrum of the complex Adenosine-5'-triphosphate, with $\mathrm{UO}_{2}{ }^{2+}$.

Figs. 1 and 2 show the laboratory unit and X-ray spectrum of the complex Adenosine with $\mathrm{UO}_{2}{ }^{2+}$ and $\mathrm{Th}^{4+}$.

Table 1 shows the elemental composition of the complex Adenosine with uranium $\left(\mathrm{UO}_{2}{ }^{2+}\right)$ and thorium $\left(\mathrm{Th}^{4+}\right)$ ions.
Thus, the authors obtained a complex of adenosine with uranium $\mathrm{UO}_{2}{ }^{2+}$ and thorium $\mathrm{Th}^{4+}$ ions and X-ray method to explore these complexes.

Fig. 3 shows the IR (infrared spectroscopy) spectra of the complexes Adenosine, Guanosine and Cytidine with $\mathrm{UO}_{2}{ }^{2+}$ ions. 
Table 1 Elemental composition of the complex Adenosine with $\mathrm{UO}_{2}{ }^{2+}$ and $\mathrm{Th}^{4+}$ ions.

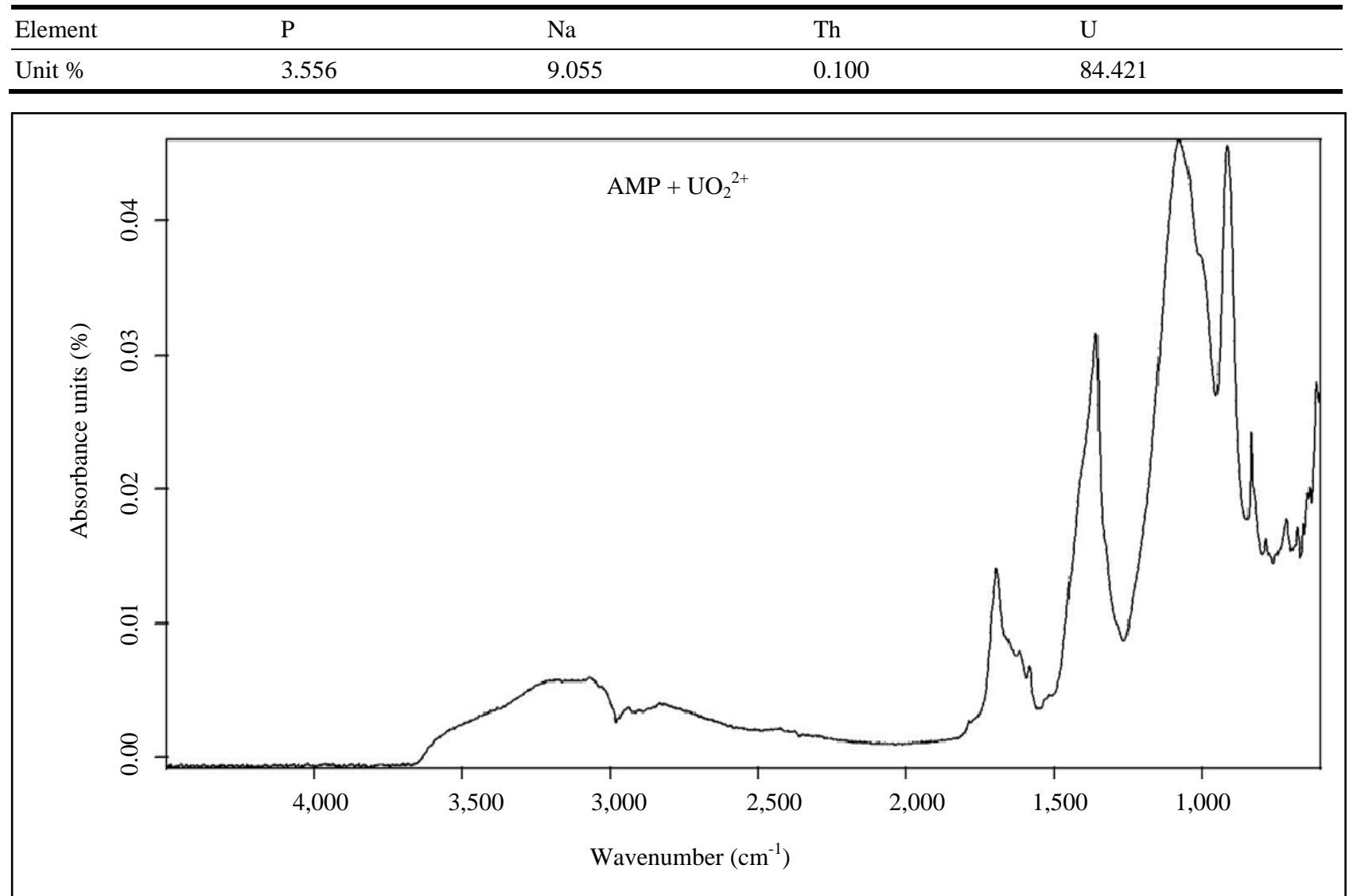

(a)

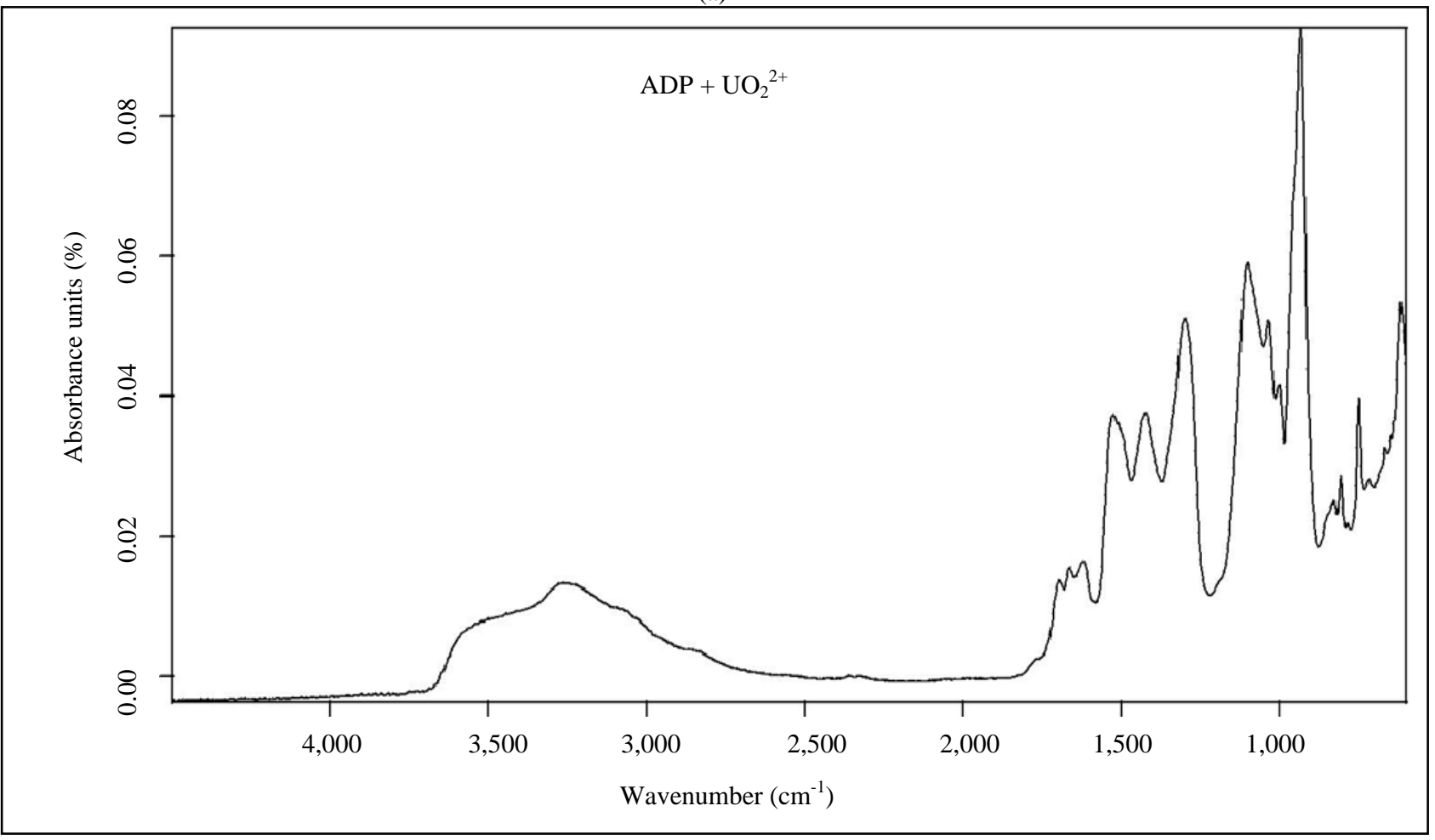

(b) 


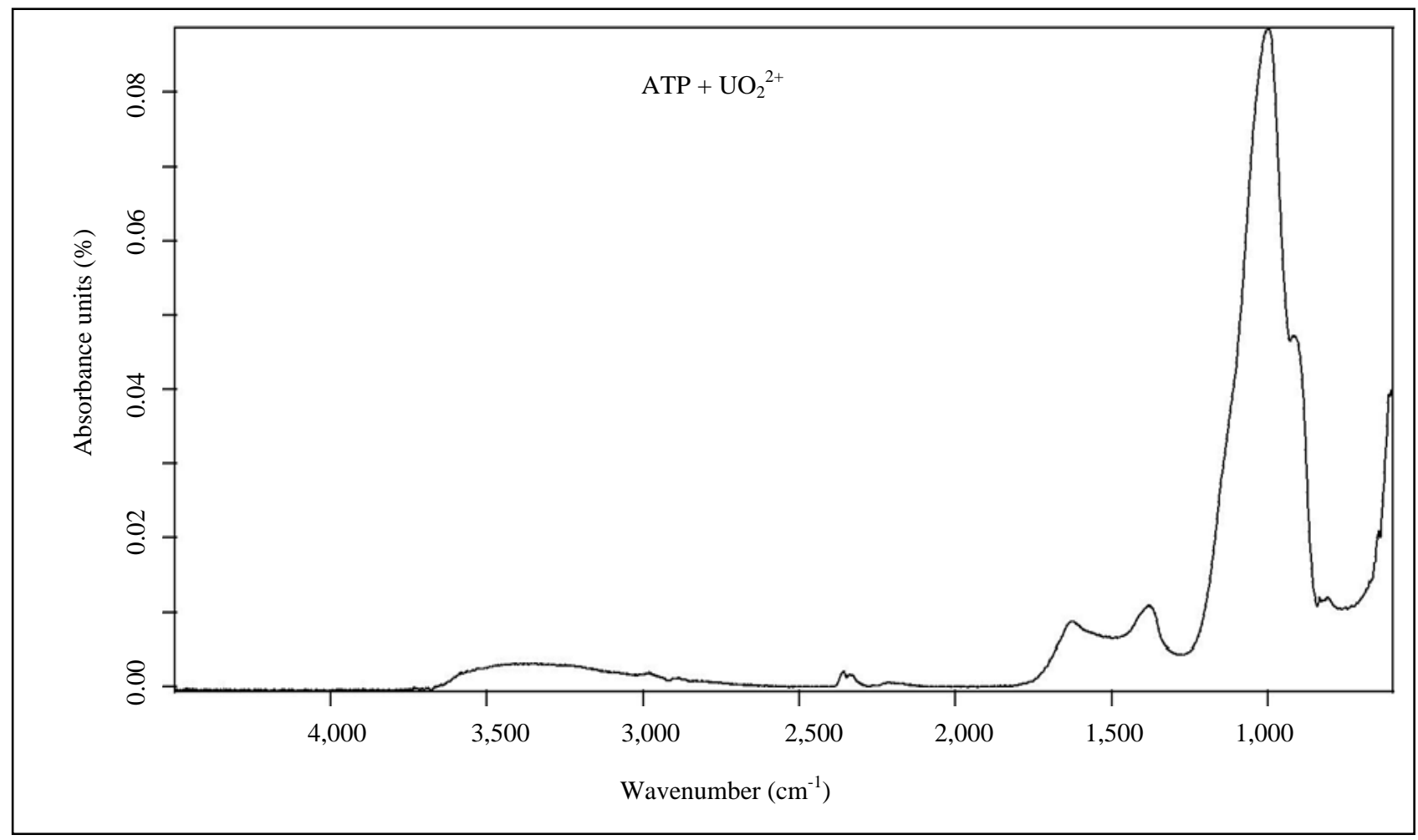

(c)

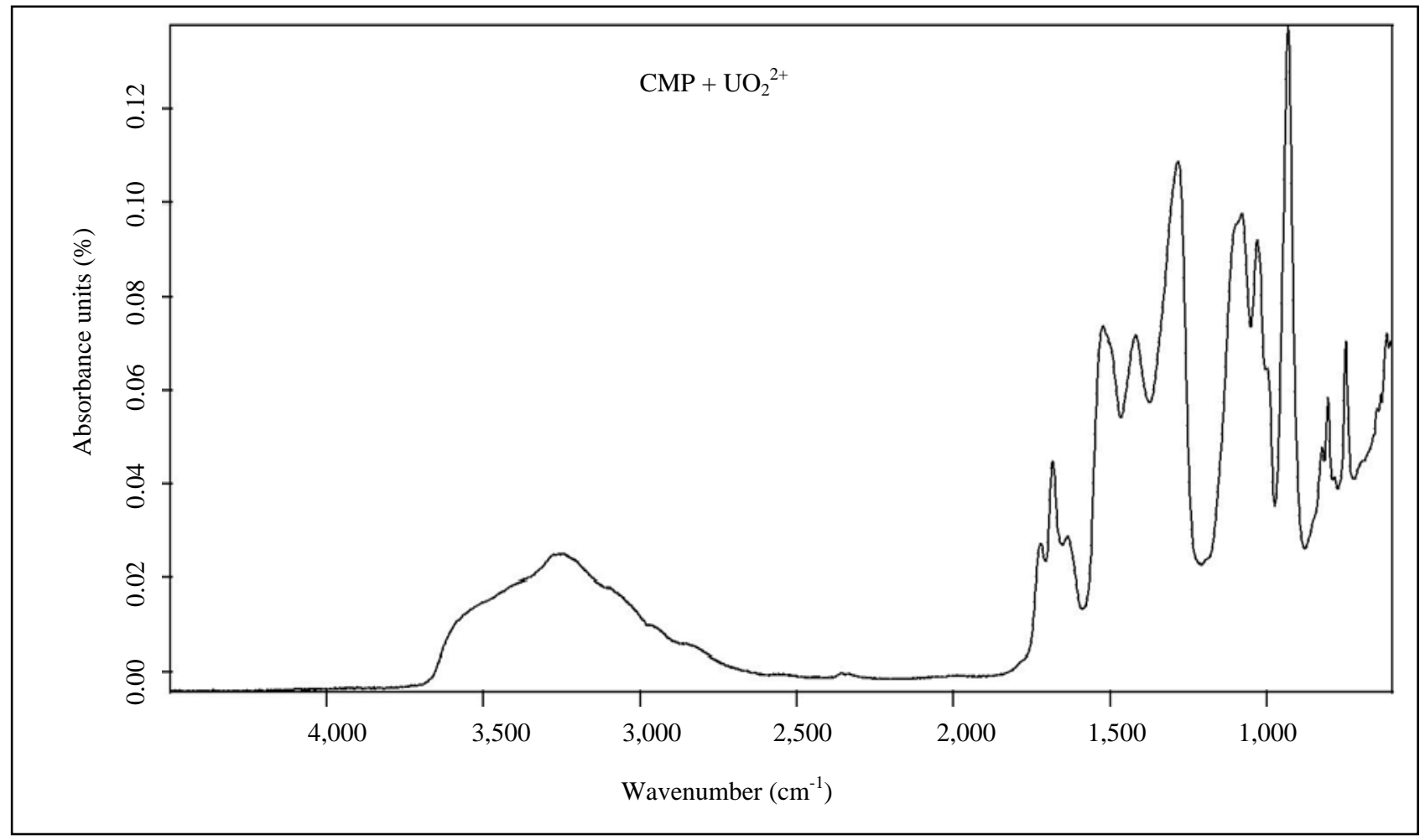

(d) 


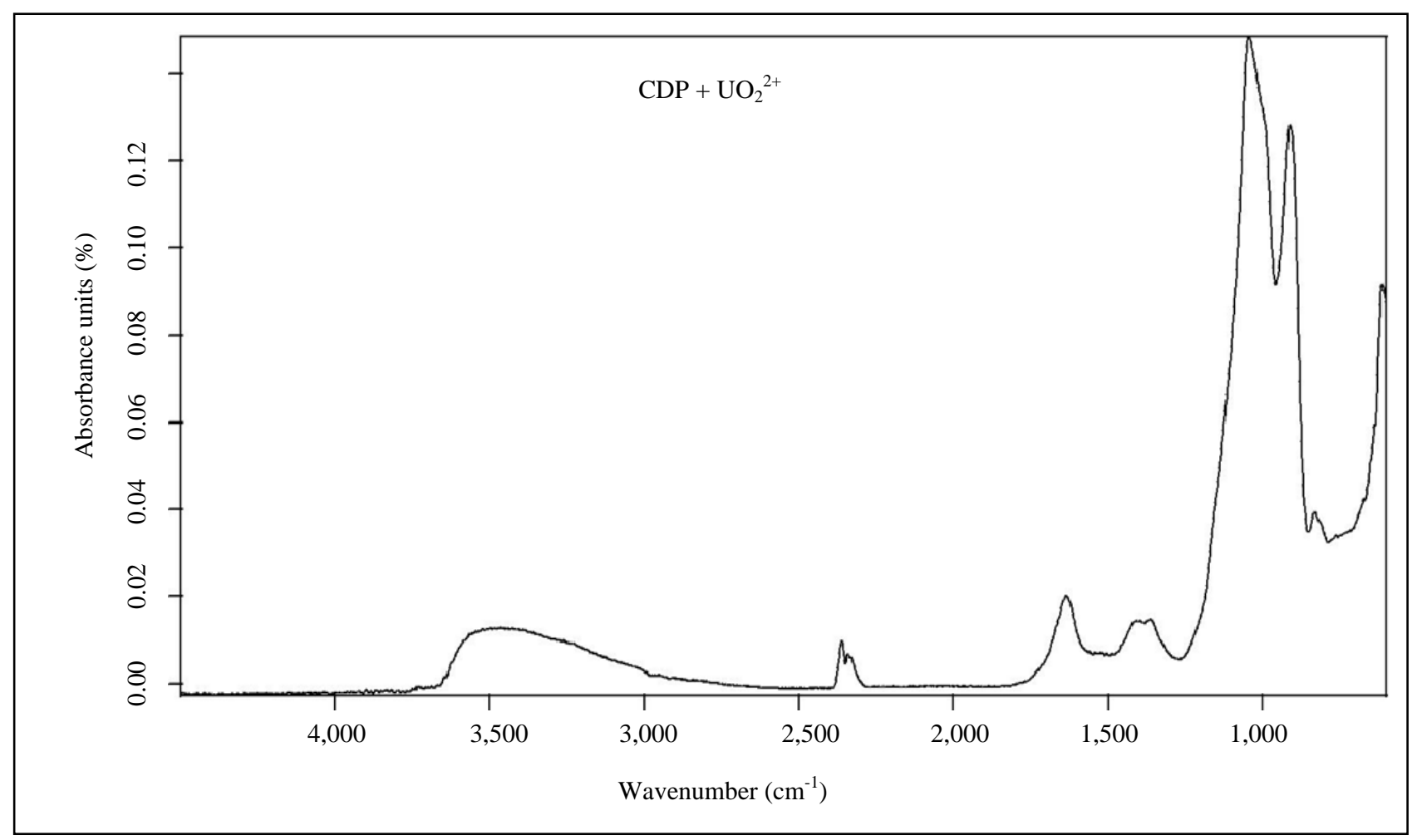

(e)

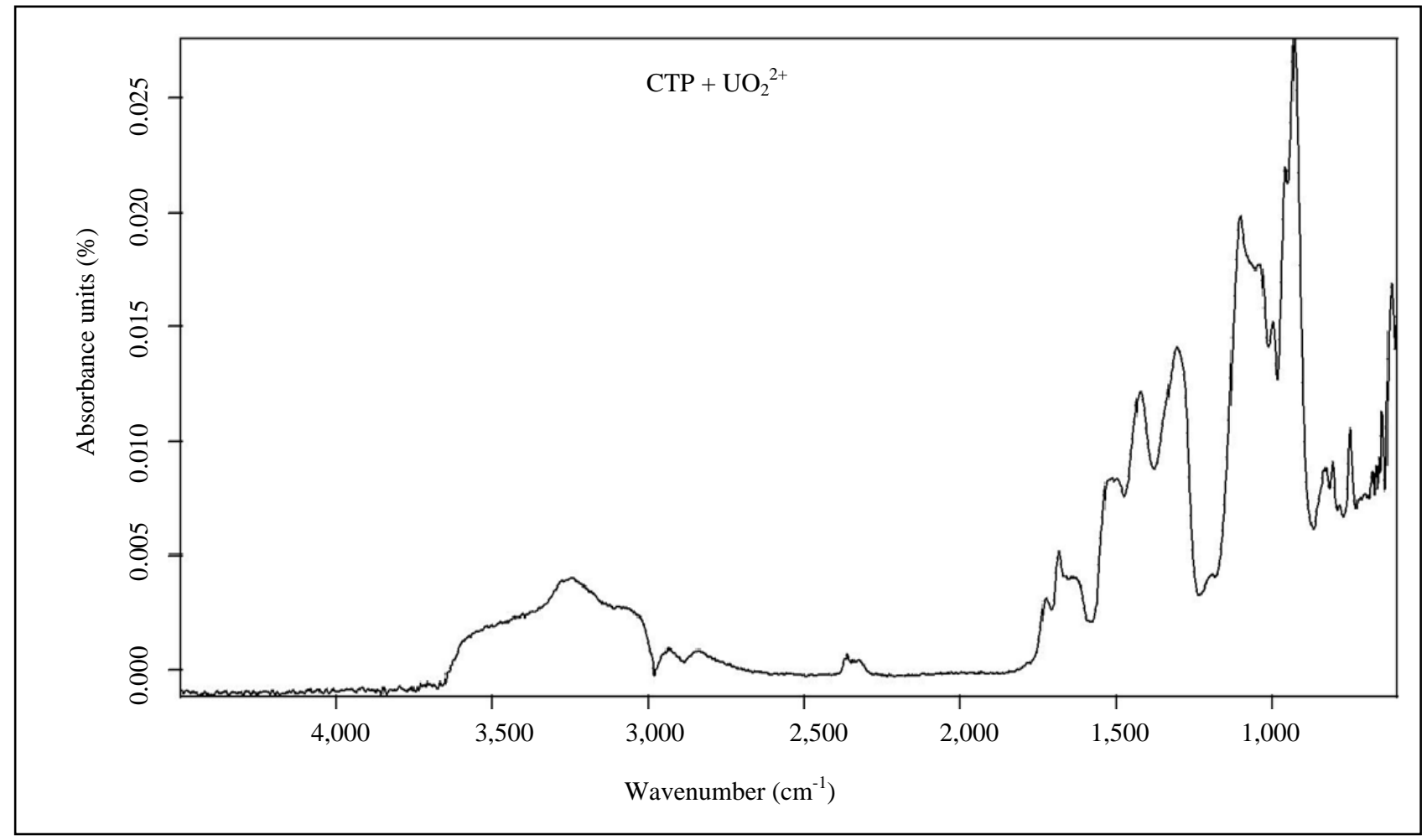

(f) 


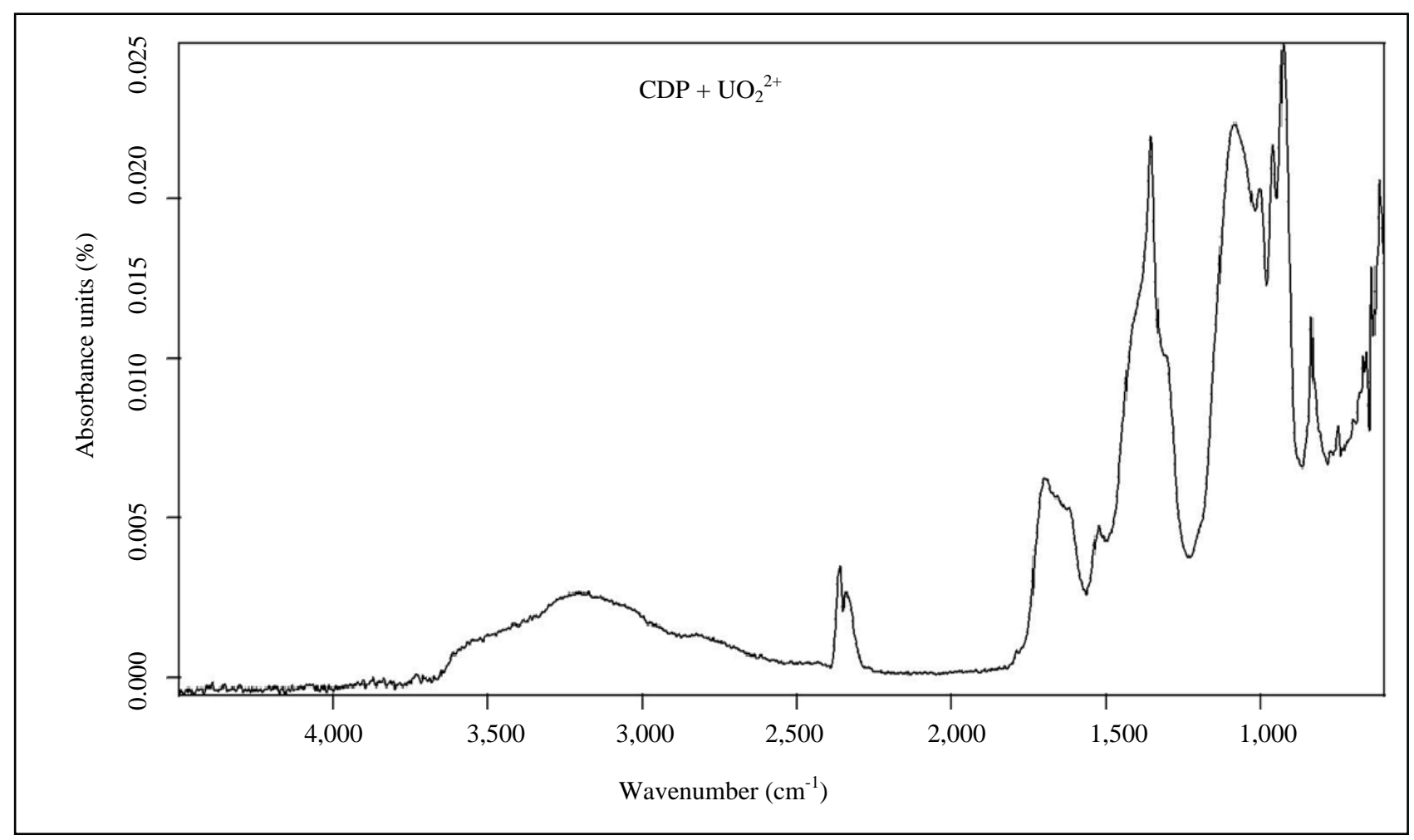

(g)

Fig. 3 IR spectrum of the complex ATP (a), ADP (b), AMP (c), CTP (d), CDP (e), CMP (f), CDP (g) with UO ${ }_{2}{ }^{2+}$.

Thus, the authors obtained a complex of ATP, ADP, AMP, CTP, CDP, CMP, GDP with uranium $\mathrm{UO}_{2}{ }^{2+}$ ions and IR spectra and X-ray method to explore these complexes.

\section{Conclusions}

Interaction of dioxouraniun (VI) $\mathrm{UO}_{2}{ }^{2+}$ ions with ATP, ADP, AMP, CTP, CDP, CMP, GDP was obtained a complex of adenosine with uranium $\mathrm{UO}_{2}{ }^{2+}$ ions and X-ray method to explore these complexes.

\section{Acknowledgments}

The authors would like to thank Lynn C. Francesconi (Hunter College CUNY), Ruben $\mathrm{M}$. Savizky (Columbia University, New York), Peter C. Burns (Notre Dame University, Indiana) and Chistopher L. Cahill (George Washington University) for discussion of the results.

\section{References}

[1] Stefano, C. D., Gianguzza. A., Pettignano, A., and
Sammartano, S. 2005. "Interaction of $\mathrm{UO}_{2}{ }^{2+}$ with ATP in Aqueous Ionic Media.” Biophys. Chem. 117 (2): 147-53.

[2] Feldman, I., Jones, J., and Cross, R. 1967. "Chelation of Uranyl Ions by Adenine Nucleotides.” J. Am. Chem. Soc. 89 (1): 49-53.

[3] Feldman, I., Rich, K. E., and Agarwal, R. T. 1970. "Chelation of Uranyl Ions by Adenine Nucleotides: IV. Nuclear Magnetic Resonance Investigations, Hydrogen-1 and Phosphorus-31, of the Uranyl-Adenosine 5'-diphosphate and Uranyl-Adenosine 5'-triphosphate Systems.” J. Am. Chem. Soc. 92 (23): 6818-25.

[4] Ozmen, M., and Yurekli, M. 1998. "Subacute Toxicity of Uranium Acetate in Swiss-Albino Mice.” Environ. Toxicol. Pharmacol. 6 (2): 111-5.

[5] Domingo, J. I., Llobet, J. M., Tomás, J. M., and Corbella, J. 1987. “Acute Toxicity of Uranium in Rats and Mice.” Bull. Environ. Contam. Toxicol. 39 (1): 168-74.

[6] Ballon, J. E., Gies, R. A., Case, A. C., Haggard, D. L., Buschbom, R. L., and Ryan, J. L. 1986. "Deposition and Early Disposition of Inhaled ${ }^{233} \mathrm{UO}_{2}\left(\mathrm{NO}_{3}\right)_{2}$ and ${ }^{232} \mathrm{UO}_{2}\left(\mathrm{NO}_{3}\right)_{2}$ in the Rats." Health Phys. 51 (6): 755-71.

[7] Harvey, R. B., Kubena, L. F., Lovering, S. L., Mollenhauer, H. H., and Phillips, T. D. 1986. “Acute Toxicity of Uranyl Nitrate to Growing Chicks: A Pathophysiologie Study.” Bull. Environ. Contam. Toxicol. 
37 (1): 907-15.

[8] Garten, C. T. 1978. "A Review of Parameter Values used to Access the Transport of Plutonium, Uranium and Thorium in Terrestrial Food Chaims.” Environ. Res. 17: 437.

[9] Guillaumont, R. 2003. “Chemical Thermodynamics Series. Update on the Chemical Thermodynamics of Uranium, Neptunium, Plutonium, Amercium and Technecium.” Vol. 5, OECD Nuclear Energy Agency, Elsevier Scienze and References Therein.

[10] De Stefano, C., Gianguzza, A., Leggio, T., and Sammartano, S. 2002. "Dependence on Ionic Strength of Hydrolysis Constants for Dioxouranium (VI) in $\mathrm{NaCl}_{(\mathrm{aq})}$ and $\mathrm{NaNO}_{3 \text { (aq) }}$ at $\mathrm{pH}<6$ and $\mathrm{t}=25{ }^{\circ} \mathrm{C}$.” J. Chem. Eng.
Data 47: 533-8.

[11] Giangezza, A., Milea, D., Milleroc, F. J., and Sammartano, S. 2004. "Hydrolysis and Chemical Speciation of Dioxouranium (VI) Ion in Aqueous Media Simulating the Major Composition of Seawater." Mar. Chem. 85 (3-4): 103-24.

[12] Crea, F., Stefano, D., Pettignano, A., and Sammartano, S. 2004. "Hydrolysis of Dioxouranium (VI) a Colorimetric Study in $\mathrm{NaCl}_{(\mathrm{aq})}$ and $\mathrm{NaClO}_{4(\mathrm{aq})}$ at $25{ }^{\circ} \mathrm{C}$." Thermochim Acta 414: 185-9.

[13] Giangezza, A., Pettignano, A., and Sammartano S. 2005. "Interaction of Dioxouranium (VI) Ion with Aspirate and Glutamate in $\mathrm{NaCl}_{\mathrm{aq}}$ at Different Ionic Strengths." $J$. Chem. Eng. Data 50 (5): 1576-81. 